\title{
ANALISIS PENDAPATAN USAHATANI PADI SAWAH \\ DENGAN METODE SRI (System of Rice Intensification) DI DESA EMPAT BALAI KECAMATAN KUOK KABUPATEN KAMPAR
}

\author{
Mario Francisco Tamba ${ }^{1)}$, Evy Maharani ${ }^{2)}$, Susy Edwina ${ }^{2)}$ \\ Jurusan Agribisnis Fakultas Pertanian UNRI \\ Email: marioftamba@gmail.com
}

\begin{abstract}
ABSTRAK
Tanaman padi merupakan salah satu tanaman utama dalam pertanian mengingat nasi adalah salah satu makanan pokok di Indonesia. Adopsi dan inovasi dari budidaya padi diperlukan dikarenakan lahan untuk tanaman pangan sudah banyak dialihfungsikan sebagai lahan industri atau lahan perkebunan. Penelitian ini bertujuan untuk melihat adopsi dari teknik budidaya yang dilakukan oleh petani. Selain itu penelitian ini bertujuan untuk melihat efisiensi dari usahatani yang dilakukan. Penelitian ini dilakukan di Desa Empat Balai Kecamatan Kuok Kabupaten Kampar. Hasil penelitian menunjukkan bahwa terdapat beberapa perbedaan dalam budidaya padi yang dilakukan dengan menggunakan metode SRI dan metode konvensional yang selama ini dilakukan oleh petani. Perbedaan dari budidaya padi SRI dengan konvensional terdapat pada jumlah bibit per lubang tanam dan penggunaan pupuk. Jumlah bibit yang digunakan pada metode SRI hanya menggunakan 1 bibit per sedangkan penggunaan pupuk lebih mengutamakan penggunaan bahan-bahan organik seperti keong mas, air beras, air kelapa dan gula merah.Selain itu terdapat peningkatan produksi beras dari hasil metode SRI dimana mencapai produksi sebesar 3.014,51 kg per ha. Peningkatan produksi mengakibatkan total pendapatan bersih dari hasil produksi beras metode SRI meningkat sebesar Rp.14.953.667,01 per ha. Nilai RCR pada usahatani ini adalah 1,76 per ha, dimana nilai RCR > 1 maka usahatani ini masuk dalam kategori mengutungkan.
\end{abstract}

Kata Kunci: Usahatani, Padi, SRI, Pendapatan, Efisiensi 


\title{
INCOME ANALYZING OF PADDY FARMING BY USING SRI METHOD (System of Rice Intencification) IN EMPAT BALAI VILLAGE KUOK SUB- DISTRICT KAMPAR MUNICIPALITY
}

\author{
Mario Francisco Tamba ${ }^{1)}$, Evy Maharani ${ }^{2)}$, Susy Edwina, ${ }^{2)}$ \\ Agribusiness Department Agricultural Faculty University of Riau \\ Email: marioftamba@gmail.com
}

\begin{abstract}
ABSTRAK
Paddy is one of main farming commodity since rice is one of main food in Indonesia. Innovation adoption about paddy farming was meaningful, because there were land conversion from food farming to industrial land or plantation. This study aimed to know about the adoption of farming technical was used by farmers, then aimed to know the efficiency of farming. This study took place in Empat Balai Village Kuok Sub-district Kampar Municipality. The results of this study showed there were differences about faming technical between faming technical with SRI and conventional faming technical that was used for a long time. The differences between SRI paddy farming and conventional farming were the amount of seeds per planted hole and the use of fertilizers. The amount of seeds on SRI method was only 1 seed per planted hole, meanwhile the use of fertilizers was more prioritize on using the organic materials i.e. golden snail, rice water, and brown sugar. On the other hand, there was an increasing of paddy production from SRI method which reached the production of 3.014,51 kg per ha. The increase of production caused the increase of total net income by SRI method Rp.14.953.667,01 per ha. RCR value of this farming was 1,76 per ha, which the value of RCR > 1 then this farming was profitable categorized.
\end{abstract}

Keywords: Farming, Paddy, SRI, Income, Efficiency

\section{PENDAHULUAN}

Pembangunan pertanian merupakan bagian bagian dari pembangunan ekonomi dan masyarakat secara umum. Pembangunan pertanian memberikan sumbangan kepada masyarakat serta menjamin bahwa pembangunan yang menyeluruh itu mencakup penduduk yang hidup dari bertani, yang jumlahnya besar dan untuk tahun tahun datang (Krisnandi, 2009). Tanaman padi adalah salah satu tanaman utama dalam bidang pertanian. Padi menghasilkan beras dan beras adalah makanan pokok sebagian besar masyarakat Indonesia. Pada saat ini lahan pertanian di Indonesia yang dialokasikan untuk berbudiya tanaman pangan khususnya budidaya padi sudah sangat sedikit. Para petani banyak yang melakukan alihfungsi lahan menjadi lahan perkebunan atau perindustrian yang dimana menurut 
mereka tingkat kesejahteraan petani tanaman pangan lebih kecil jika dibandingkan dengan tingkat kesejahteraan petani yang melakukan usahatani di bidang perkebunan atau yang bekerja di bidang perindustrian.

Produksi padi di Indonesia mengalami fluktuatif setiap tahunnya. Berdasarkan data BPS pada tahun 2014, produksi padi di Indonesia mencapai 70,83 juta ton, mengalami penurunan sebesar $0,63 \%$ atau 0,45 juta ton dari hasil produksi padi pada tahun 2013 yang mencapai 71,27 juta ton.

Perkembangan tanaman padi di Riau sejalan dengan perkembangan tanaman padi di Indonesia. Perkembangan luas panen dan produksi di Riau juga fluktuatif. Pada tahun 2012 luas panen di Riau mencapai 144.000 ha dan mengalami penurunan yang signifikan pada tahun 2013 menjadi 118.500 ha. Penurunan luas panen ini juga berimbas kepada penurunan jumlah produksi padi di Riau. Pada tahun 2012 produksi padi di Riau berjumlah 512.200 ton, mengalami penurunan pada tahun 2013 menjadi 434.100 ton (BPS, 2014). Berikut adalah trend penurunan produksi dan luas panen di Riau.

Lahan pertanian yang sudah banyak dialihfungsikan menjadi lahan perkebunan atau perindustrian yang mengakibatkan kemampuan bertani padi sudah semakin berkurang. Semakin banyaknya lahan pertanian yang berkurang maka produksi semakin sedikit, sehingga diperlukan adopsi inovasi dalam budidaya tanaman pertanian khususnya padi.

Pola budidaya yang selama ini dilakukan oleh petani di Desa Empat Balai ini adalah dengan metode konvensional. Adopsi yang sudah dilakukan oleh petani dalam budidaya adalah dengan mengganti metode konvensional yang selama ini dipakai oleh petani dengan memakai metode SRI, dimana dalam metode SRI ini dapat meningkatkan jumlah produksi dibandingkan dengan metode konvensional yang selama ini dipakai oleh petani.

Tujuan dari penelitian ini adalah 1). Untuk mengetahui penerapan sistem usahatani padi sawah dengan metode SRI yang dilakukan oleh petani di Desa Empat Balai Kecamatan Kuok Kabupaten Kampar, 2). Untuk menganalisis pendapatan dan efisiensi usahatani padi sawah dengan metode SRI di Desa Empat Balai Kecamatan Kuok Kabupaten Kampar.

\section{METODE PENELITIAN Waktu dan Tempat Penelitian}

Penelitian ini dilakukan di Desa Empat Balai Kecamatan Kuok Kabupaten Kampar. Lokasi ini dipilih dikarenakan adopsi inovasi sistem tanam SRI di Kabupaten Kampar baru dimulai di Desa ini. Waktu dilakukannya penelitian ini adalah dari bulan Januari - Mei 2016.

\section{Metode Pengambilan Data}

Metode pengambilan data adalah dengan survei dengan langsung turun ke petani menggunakan kuesioner. Jumlah petani yang menggunakan metode SRI ini adalah 40 petani yang tergabung dalam satu kelompok tani. Responden yang diambil dari penelitian ini adalah 40 petani, dikarenakan jumlah keseluruhan populasi kurang dari 100 sehingga seluruh populasi dijadikan sampel. 


\section{Jenis dan Sumber Data.}

Sumber data dalam terbagi dua, yaitu data primer dan data sekunder. Data primer diperoleh dari instansi instansi terkait seperti BPS, Dinas Pertanian Kabupaten Kampar, Balai Penyuluh Pertanian Kecamatan Kuok dan juga literatur dan artikel yang terkait. Data sekunder diperoleh dari hasil wawancara langsung dengan petani.

\section{Analisis Data}

Analisis data dalam penelitian ini menggunakan analisis deskriptif dan kuantitatif. Analisis data yang dilakukan

1). Untuk mengetahui penerapan sistem usahatani dengan metode SRI dilakukan analisis deskriptif dengan memaparkan penerapan yang dilakukan oleh petani di lapangan.

2). Untuk menganalisis biaya produksi dan pendapatan dilakukan analisis kuantitatif. Menurut Soekartawi (2002), untuk menganalisis biaya produksi dapat dilakukan dengan

Keterangan:

$$
\mathrm{TC}=\mathrm{TFC}+\mathrm{TVC}
$$

$\mathrm{TC}=$ Biaya Total $(\mathrm{Rp} / \mathrm{Ha} / \mathrm{Musim}$ Tanam)

TFC $=$ Total Biaya Tetap (Rp/Ha/Musim Tanam)

$\mathrm{TVC}=$ Total Biaya Variabel (Rp/Ha/Musim Tanam).

Menurut Sukirno (2002), untuk menghitung pendapatan dapat digunakan rumus

Keterangan:

$$
\mathrm{TR}=\mathrm{P} \times \mathrm{Q}
$$

$\mathrm{TR}=\quad$ Total Penerimaan
$(\mathrm{Rp} / \mathrm{Ha} /$ Musim Tanam $)$
$\mathrm{P}=$ Harga Produk $(\mathrm{Rp} / \mathrm{Kg})$
$\mathrm{Q}=$ Jumlah Produk $(\mathrm{Kg} / \mathrm{Ha} / \mathrm{Musim}$ Tanam.

Menurut Harnanto (2003), efisiensi usahatani adalah perbandingan antara penerimaan dan biaya dimana biaya lebih besar dibandingkan dengan total biaya. Efisiensi usahatani dapat dihitung dengan menggunakan rumus

$$
\mathrm{RCR}=\frac{\mathrm{TR}}{\mathrm{TC}}
$$

Keterangan:

RCR $<1$ = Usahatani mengalami kerugian

RCR $=1$ = Usahatani mencapai titik impas

RCR > 1 = Usahatani mengalami keuntungan.

\section{HASIL DAN PEMBAHASAN \\ Penerapan Budidaya Metode SRI oleh Petani}

Teknik budidaya padi SRI dengan budidaya padi konvensional yang dilakukan oleh petani tidak jauh berbeda. Perbedaan yang utama adalah pada penggunaan bibit per lubang tanamnya, penggunaan pupuk, dari segi produksi yang dihasilkan dengan sistem tanam SRI ini lebih baik dibandingkan dengan sistem tanam konvensional.

Hasil produksi sistem tanam SRI lebih baik dibandingkan dengan hasil produksi dengan sistem tanam konvensional dikarenakan penggunaan bibit per lubang tanam pada metode SRI yang hanya satu bibit per lubang tanam sehingga unsur - unsur hara yang diperlukan oleh bibit dalam masa pertumbuhannya dapat diperoleh dengan baik. Selain itu, dengan menggunakan satu bibit per lubang tanam dapat membuat malai padi tersebut mendapatkan cukup ruang sehingga bulir padi yang dihasilkan lebih banyak dibandingkan dengan sistem tanam konvensional. 
Tabel 1. Penerapan Petani Padi dengan Sistem Tanam SRI

\begin{tabular}{|c|c|c|c|}
\hline No & Sistem Konvensional & Sistem SRI & $\begin{array}{l}\text { Penerapan oleh } \\
\text { Petani Padi } \\
\text { dengan Sistem } \\
\text { SRI }\end{array}$ \\
\hline 1 & $\begin{array}{l}\text { Proses Penyemaian Dapat Mencapai } \\
25 \text { hari }\end{array}$ & Proses Penyemaian 15 hari & $\mathrm{Ya}$ \\
\hline 2 & $\begin{array}{l}\text { Penanaman Tidak Langsung Setelah } \\
\text { Pencabutan Benih dari Persemaian }\end{array}$ & $\begin{array}{l}\text { Penanaman Langsung } \\
\text { Setelah Benih Dicabut dari } \\
\text { Persemaian }\end{array}$ & Ya \\
\hline 3 & $\begin{array}{l}\text { Penggunaan } 5 \text { - } 7 \text { benih per lubang } \\
\text { tanam }\end{array}$ & $\begin{array}{l}\text { Penggunaan } 1 \text { benih per } \\
\text { lubang tanam }\end{array}$ & Tidak \\
\hline 4 & $\begin{array}{l}\text { Jarak Tanam } 15 \times 15 \mathrm{~cm} \text { atau } 20 \mathrm{x} \\
20 \mathrm{~cm}\end{array}$ & Jarak Tanam $25 \times 25 \mathrm{~cm}$ & Ya \\
\hline 5 & Penggunaan Pupuk Kimia & Penggunaan Pupuk Organik & Ya \\
\hline 6 & Penggunaan Pestisida Kimia & $\begin{array}{l}\text { Penggunaan Pestisida } \\
\text { Organik }\end{array}$ & Ya \\
\hline 7 & $\begin{array}{l}\text { Penyiangan Dilakukan dengan } \\
\text { Menggunakan Bahan - Bahan Kimia }\end{array}$ & $\begin{array}{l}\text { Penyiangan Dilakukan } \\
\text { dengan Mencabut Gulma dari } \\
\text { Lahan }\end{array}$ & $\mathrm{Ya}$ \\
\hline
\end{tabular}

1. Persiapan Benih

Benih yang digunakan oleh petani dengan sistem tanam SRI ini adalah benih IR -42 dan padi kuning (unggul lokal). Benih yang digunakan pada sistem tanam ini sama dengan benih yang digunakan oleh petani dengan sistem tanam konvensional yang selama ini digunakan. Kebutuhan benih per ha pada sistem SRI ini adalah $6,93 \mathrm{~kg}$ per ha, berbeda dengan kebutuhan benih yang selama ini digunakan oleh petani pada sistem tanam konvensional yang mencapai $20-25$ $\mathrm{kg}$ per ha.

Sebelum melakukan persemaian, benih diseleksi terlebih dahulu dengan menggunakan telur dan larutan air garam. Benih yang baik untuk digunakan adalah benih yang tenggelam sedangkan benih yang terapung adalah benih yang tidak baik untuk digunakan. Setelah melakukan penyeleksian benih, petani melakukan persemaian. Rata rata waktu persemaian bibit oleh petani adalah 13 hari.
2. Pengolahan Tanah

Pengolahan tanah yang dilakukan oleh petani dengan sistem tanam SRI tidak berbeda dengan pengolahan tanah dengan sistem tanam konvensional yang selama ini digunakan oleh petani. Petani melakukan pengolahan tanah 14 hari sebelum masa tanam. Pembajakan dilakukan oleh petani dengan menggunakan mesin traktor, kemudian pengolahan tanah selanjutnya dilakukan dengan menggunakan tenaga manusia.

\section{Penanaman}

Setelah melakukan penyemaian, petani langsung memindahkan bibit yang disemai tersebut ke lahan tempat penanaman. Hal ini berbeda jika dibandingkan dengan sistem tanam konvensional dimana bibit tersebut dapat didiamkan selama satu malam sebelum dilakukan penanaman. Bibit yang tidak langsung ditanam akan menguning sehingga dalam sistem tanam SRI bibit tersebut langsung ditanam 
setelah diambil dari tempat persemaian.

4. Pemupukan

Salah satu faktor yang membedakan sistem tanam SRI dengan sistem tanam konvensional adalah penggunaan pupuk. Pupuk yang digunakan oleh petani dalam sistem tanam konvensional adalah pupuk kimia seperti urea, tsp dan kcl namun pada sistem SRI petani tidak ada memakai pupuk kimia tersebut. Pupuk yang digunakan oleh petani adalah Mikroorganisme Lokal (MOL). Bahan - bahan yang digunakan dalam pembuatan MOL adalah bahan - bahan yang diperoleh dari alam seperti rebung, bonggol pisang, keong mas, air beras, air kelapa dan gula merah. Penggunaan pupuk MOL selama masa tanam oleh petani sebanyak dua kali yaitu 15 hari setelah masa tanam dan 35 hari sebelum masa panen.

\section{Pemeliharaan}

Pemeliharaan yang dilakukan oleh petani dengan sistem tanam SRI ini meliputi penyiangan. Teknik penyiangan sistem tanam SRI berbeda dengan teknik penyiangan pada sistem tanam konvensional. Pada sistem tanam konvensional petani menggunakan obat - obatan kimia untuk mencegah pertumbuhan gulma di lahan mereka, namun pada sistem tanam SRI petani melakukan dengan cara manual dengan mencabut gulma langsung dari lahan mereka. Hal ini dilakukan agar struktur tanah tetap terjaga. Penyiangan dilakukan sebanyak tiga kali selama satu musim tanam yaitu 15 hari setelah masa tanam, kemudian 35 hari setelah masa tanam, dan terakhir 50 hari setelah masa tanam.

Pemeliharaan lain yang dilakukan oleh petani adalah pengairan. Berbeda dengan sistem tanam konvensional, pola pengairan pada sistem tanam SRI ini adalah pola macak - macak, dimana ketinggian air $0,5-2 \mathrm{~cm}$. Pola macak - macak adalah pola pengairan yang tidak membiarkan air tersebut tergenang di lahan $(0,5 \mathrm{~cm})$.

Pemeliharaan lain yang dilakukan oleh petani adalah pemberantasan hama dan penyakit. Pada sistem tanam konvensional petani menggunakan bahan - bahan kimia dalam mengendalikan hama dan penyakit, namun pada sistem tanam SRI petani menggunakan MOL dalam mengendalikan hama. Aroma - aroma yang ditimbulkan dari MOL tersebut dapat mengusir hama yang terdapat dalam lahan petani tersebut.

\section{Pemanenan}

Petani melakukan pemanenan ketika umur tanaman sudah mencapai 100 hari. Teknik melakukan pemanenan padi sawah dengan metode SRI tidak berbeda dengan metode konvensional, namin perbedaan terletak pada waktu pemanenan. Waktu pemanenan dalam metode konvensional dapat mencapai 120 hari terhitung sejak dilakukan persemaian, namun pada sistem tanam SRI waktu pemanenan lebih singkat dikarenakan waktu persemaian metode SRI lebih singkat jika dibandingkan dengan waktu 
persemaian dengan metode konvensional.

\section{Analisis Usahatani Padi Sawah dengan Metode SRI}

\section{Biaya Variabel}

Biaya Variabel adalah biaya produksi yang jumlahnya berubah -

ubah sesuai dengan besar kecilnya produksi. Biaya - biaya variabel dalam penelitian ini terdiri dari benih, pupuk, biaya TKLK, dan biaya pengolahan.

Tabel 2. Total Biaya Variabel Usahatani Padi Sawah dengan Metode SRI

\begin{tabular}{llrr}
\hline \multirow{2}{*}{ No } & \multicolumn{1}{c}{ Uraian Biaya } & $\begin{array}{r}\text { Total (Rp/Ha/Musim } \\
\text { Tanam) }\end{array}$ & $\begin{array}{r}\text { Persentase } \\
(\%)\end{array}$ \\
\hline 1 & Benih & $41.613,00$ & 0,82 \\
2 & Pupuk Kandang & $709.995,00$ & 14,06 \\
3 & Abu Gosok & $30.459,00$ & 0,60 \\
4 & Pupuk Mikroorganisme Lokal & $18.418,04$ & 0,36 \\
5 & (MOL) & $42.203,16$ & 0,84 \\
6 & Biaya Transportasi & & \\
& Tenaga Kerja Luar Keluarga & & \\
& A. Pembajakan & $900.900,00$ & \\
& B. Pengolahan Tanah & $915.200,00$ & \\
C. Penebaran Pupuk Kandang & $95.059,25$ & \\
& D. Penanaman & $80.080,00$ & \\
E. Pemupukan & $20.020,00$ & \\
F. Penyiangan & $433.290,00$ & \\
G. Pemanenan & $1.218 .360,00$ & \\
& & $3.662 .909,25$ & 72,56 \\
7 & Pengolahan & & \\
A. Pengemasan & $180.870,69$ & \\
B. Penggilingan $\quad$ Total Biaya Pengolahan & $361.741,38$ & \\
& Jumlah & $542.612,07$ & 10,75 \\
\hline
\end{tabular}

Benih yang digunakan petani dalam sistem tanam SRI adalah IR 42 dan padi kuning (unggul lokal). Benih yang digunakan dalam sistem SRI ini sama dengan benih yang digunakan oleh petani dengan sistem tanam konvensional. Rata - rata kebutuhan benih dalam penelitian ini adalah 6,93 kg/ha. Harga benih tersebut adalah Rp.6.000,00 per kg sehingga biaya yang dikeluarkan oleh petani untuk pembelian benih adalah Rp.41.613,00 per ha.

Rata - rata penggunaan benih metode konvensional di Desa Sungai Geringging Kecamatan Kampar Kiri Kabupaten Kampar dalam penelitian Filardi dan Elida (2014) dimana petani tersebut menggunakan metode konvensional adalah $13 \mathrm{~kg}$ per ha dengan total biaya untuk benih sebesar Rp.156.000,00 per ha. 
Penggunaan pupuk oleh petani dalam sistem tanam SRI ini adalah pupuk MOL. Bahan - bahan yang digunakan dalam pembuatan pupuk ini adalah keong mas, air beras, air kelapa dan gula merah. Petani membuat indukan MOL secara bersama - sama dan dibagi rata sesuai dengan luasan lahan yang dimiliki oleh petani tersebut. Rata rata biaya untuk pembuatan MOL adalah Rp.18.418,04 per ha.

Biaya pupuk lain yang dikeluarkan oleh petani adalah untuk pembelian pupuk kandang. Rata rata penggunaan pupuk kandang untuk setiap hektar adalah 71 karung dengan ukuran karung $50 \mathrm{~kg}$ atau sebanyak 355,00 kg. Harga dari pupuk kandang tersebut adalah Rp.10.000,00 per karung sehingga total biaya untuk pembelian pupuk kandang adalah Rp.710.000,00.

Rata - rata penggunaan pupuk dalam penelitian Filardi dan Elida (2014) adalah Rp.1.745.312,50 per ha dengan rata - rata penggunaan pupuk kimia sebanyak 199,72 kg. Pupuk kimia yang digunakan adalah urea, TSP, dan KCL.

Penggunaan tenaga kerja merupakan salah satu faktor penting dalam budidaya. Tenaga kerja terbagi atas dua yaitu tenaga kerja luar keluarga dan tenaga kerja dalam keluarga. Upah tenaga kerja dalam penelitian ini adalah Rp.80.000,00 untuk tenaga kerja wanita dan Rp.90.0000 untuk tenaga kerja pria per hari. Total biaya TKLK dalam penelitian ini adalah Rp.3.662.909,25 per ha. Upah tenaga kerja terbesar adalah kegiatan pengolahan tanah dengan total biaya Rp.915.200,00 per ha.

Biaya tenaga kerja luar keluarga dalam penelitian Filardi dan Elida (2014) adalah Rp.1.463.372,40 dengan total penggunaan HKP sebanyak 20,74 HKP.

Biaya pengolahan adalah biaya yang dikeluarkan oleh petani selama proses pengolahan dari gabah sampai ke beras. Biaya pengolahan dalam usahatani ini meliputi biaya pengemasan dan biaya penggilingan. Total biaya penggilingan dalam usahatani ini adalah Rp.361.741,38 per ha dan total biaya pengemasan dalam usahatani ini adalah Rp.180.870,69 per ha.

Total biaya variabel dalam penelitian ini adalah Rp.5.048.209,52 per ha. Penggunaan biaya terbesar adalah TKLK dengan total biaya Rp.3.662.909,25 per ha. Biaya variabel yang digunakan dalam metode SRI lebih besar jika dibandingkan dengan biaya variabel metode konvensional. Penggunaan tenaga kerja yang lebih besar pada metode SRI mengakibatkan biaya variabel metode SRI lebih besar dibandingkan dengan metode konvensional.

\section{Biaya Tetap (Fixed Cost)}

Biaya tetap adalah biaya produksi yang besar kecilnya tidak dipengaruhi oleh besar kecilnya jumlah produksi. Biaya tetap dalam penelitian ini terdiri dari biaya sewa lahan, biaya TKDK dan penyusutan alat. Total biaya tetap dalam penelitian ini adalah Rp.14.665.005,71 per ha. 
Tabel 3. Total Biaya Tetap Usahatani dengan Metode SRI

\begin{tabular}{llrr}
\hline No & \multicolumn{1}{c}{ Uraian Biaya } & Total (Rp/Ha/Musim Tanam) & Persentase (\%) \\
\hline 1 & Sewa Lahan & $8.666 .720,56$ & 59,10 \\
2 & Penyusutan Alat & & \\
& A. Cangkul & $24.024,00$ & \\
B. Sabit & $5.898,75$ & \\
C. Handsprayer & $45.760,00$ & \\
D. Sarung Tangan $\quad 2.402,40$ & \\
\multicolumn{2}{r}{ Total Penyusutan } & $78.085,15$ & 0,53
\end{tabular}

3 TKDK
A. Pengolahan Tanah
$1.189 .402,50$
B. Penyemaian
$41.827,50$
C. Penebaran Pupuk Kandang
$141.891,75$
D. Penanaman
$320.498,75$
E. Pemupukan
$262.262,00$
F. Penyiangan
$1.814 .312,50$
G. Pemanenan
$2.150 .005,00$

\begin{tabular}{rrrr} 
& Total & $5.920 .200,00$ & 40,37 \\
\hline Jumlah & & $14.665 .005,71$ & 100,00 \\
\hline
\end{tabular}

Biaya sewa lahan dalam penelitian ini adalah dengan sistem bagi hasil. Sistem bagi hasil yang diterapkan dalam sewa lahan ini adalah $75 \%$ dari hasil produksi untuk petani penggarap dan $25 \%$ dari hasil produksi diberikan kepada pemilik lahan sebagai biaya sewa lahan. Rata - rata biaya sewa lahan per ha untuk lahan padi sawah dengan metode SRI ini adalah Rp.8.666.720,56 per ha.

Alat - alat yang digunakan oleh petani dalam usahatani dengan metode SRI ini adalah cangkul, sabit, handsprayer dan sarung tangan. Total nilai penyusutan alat per ha per musim tanam dalam usahatani ini adalah Rp.42.585,40 dengan penyusutan alat terbesar adalah cangkul dengan nilai penyusutan Rp.24.024,00 per musim tanam.

Alat - alat pertanian yang digunakan dalam metode SRI ini sama dengan alat - alat pertanian yang digunakan dalam metode konvensional. Total nilai penyusutan dalam penelitian Filardi dan Elida (2014) adalah sebesar Rp.41.255,21 per musim tanam.

Upah yang digunakan dalam perhitungan TKDK sama dengan upah yang digunakan dalam perhitungan TKLK. Total biaya untuk tenaga kerja dalam keluarga dalam usahatani ini adalah Rp.5.920.200,00 per ha. Total upah untuk tenaga kerja wanita adalah Rp.3.104.244,00 dan total upah untuk tenaga kerja pria adalah Rp.2.815.956,08 per ha.

Penggunaan TKDK dalam sistem tanam SRI lebih besar jika dibandingkan dengan penggunaan TKDK dalam usahatani dengan sistem tanam konvensional. Hal ini disebabkan dari segi penyiangan, dimana sistem tanam SRI menggunakan cara manual yaitu 
dengan mencabut gulma langsung dari lahan yang membutuhkan waktu yang lama dan tenaga kerja yang relatif lebih banyak jika dibandingkan dengan sistem tanam konvensional yang menyemprotkan bahan - bahan kimia sepert herbisida dan insektisida dalam melakukan penyiangan. Biaya TKDK dalam penelitian Filardi dan Elida (2014) adalah sebesar Rp.2.210.205,08 per ha.

Total biaya produksi adalah penggabungan biaya variabel dengan biaya tetap. Total biaya produksi dalam usahatani dengan sistem SRI ini adalah Rp.19.713.215,24 per ha. Penggunaan biaya terbesar adalah biaya tetap sebesar $74,39 \%$ dari seluruh total biaya produksi atau sebesar Rp.14.665.005,71 per ha, sedangkan untuk biaya variabel adalah sebesar $25,61 \%$ dari seluruh total biaya produksi usahatani ini atau sebesar Rp.5.048.209,52 per ha.

Total biaya produksi metode SRI lebih besar jika dibandingkan dengan total biaya produksi dengan metode konvensional seperti dalam penelitian Filardi dan Elida (2014) dimana total biaya produksi dengan metode konvensional ini sebesar Rp.7.395.629,56 per ha. Total biaya produksi metode SRI lebih besar dibandingkan dengan total biaya produksi dengan metode konvensional disebabkan oleh penggunaan tenaga kerja dalam budidaya dengan metode SRI lebih besar, terutama dalam kegiatan penyiangan.

\section{Efisensi Usahatani}

Kelayakan dari suatu usahatani dapat dilihat dari nilai Return Cost Ratio (RCR). Apabila nilai RCR tersebut lebih dari satu maka usahatani tersebut mengalami keuntungan dan layak untuk dilanjutkan. Apabila nilai RCR kurang dari satu maka usahatani tersebut mengalami kerugian dan tidak layak untuk dilanjutkan. Apabila nilai RCR sama dengan satu maka usahatani tesebut berada pada titik impas.

Tabel 4. Analisis Nilai RCR Usahatani Padi Sawah dengan Metode SRI

\begin{tabular}{clr}
\hline No & \multicolumn{1}{c}{ Uraian } & Rata - rata /Ha (Rp) \\
\hline 1 & Biaya Variabel & $5.048 .209,52$ \\
2 & Biaya Tetap & $14.665 .005,71$ \\
3 & Produksi Beras & $3.014,51$ \\
4 & Harga Jual Beras & $11.500,00$ \\
5 & Penerimaan dari Beras & $34.666 .882,25$ \\
6 & Pendapatan Kerja Keluarga & $5.920 .200,00$ \\
7 & Total Biaya Produksi & $19.713 .215,24$ \\
8 & Pendapatan Bersih & $14.953 .667,01$ \\
9 & Nilai RCR & 1,76 \\
\hline
\end{tabular}

Jumlah produksi beras dari usahatani padi sawah dengan metode SRI ini adalah $3.014,51 \mathrm{~kg}$ per ha, dengan harga beras per kg Rp.11.500 maka penerimaaan petani dari penjualan beras sebesar Rp.34.666.882,25 per ha. Pendapatan bersih petani dengan sistem tanam SRI ini adalah Rp.14.953.667,01 per 
ha. nilai RCR dalam usahatani dengan sistem tanam SRI ini adalah 1,76 dimana angka ini menunjukkan usahatani ini mengalami keuntungan sehingga layak untuk dilanjutkan.

Jumlah produksi petani padi dengan memakai metode SRI di Desa Rambah Salo Kecamatan Rambah Salo Kabupaten Rokan Hulu dalam penelitian Abdul Gafar (2014) adalah $5.245 \mathrm{~kg} / \mathrm{ha}$ gabah kering panen. Petani menjual dalam bentuk gabah kering dengan harga jual gabah tersebut Rp.3.568,00 per kg. Penerimaan petani dari penjualan gabah kering tersebut sebesar Rp.18.586.364,00 per ha. Nilai RCR dalam penelitian ini adalah 2,48 dimana angka ini menunjukkan usahatani tersebut mengalami keuntungan dan layak untuk dilanjutkan.

Jumlah produksi petani padi dengan sistem konvensional dalam penelitian Filardi dan Elida (2014) adalah sebesar 3.010,94 kg per ha gabah kering giling. Petani dalam penelitian ini menjual dalam bentuk gabah dimana harga gabah tersebut adalah sebesar Rp.12.344.843,75 per ha. Pendapatan bersih yang diterima oleh petani dalam penelitian ini adalah Rp.4.949.214,19 per ha. Nilai RCR dalam penelitian ini sebesar 1,64 dimana usahatani ini mengalami keuntungan dan layak untuk dilanjutkan.

\section{KESIMPULAN}

1. Penerapan budidaya padi dengan metode SRI oleh petani tidak seluruhnya mengikuti anjuran dari pihak penyuluh pertanian kecamatan kuok. Beberapa petani dalam penelitian ini masih menggunakan lebih dari 1 bibit per lubang tanam. Hal ini disebabkan kekhawatiran petani dengan menggunakan satu bibit per lubang tanam maka resiko untuk tidak tumbuh sangat besar.

2. Pendapatan bersih petani padi sawah dengan metode SRI ini adalah Rp.14.958.217,88 per ha per musim tanam. Nilai RCR pada usahatani ini adalah 1,76 dimana usahatani ini masuk kategori menguntungkan dan layak untuk dilanjutkan.

\section{SARAN}

1. Pihak penyuluh pertanian Kecamatan Kuok Kabupaten Kampar lebih memperhatikan para petani dalam aspek budidaya dikarenakan beberapa petani masih belum menjalankan teknis budidaya padi sawah dengan metode SRI dengan baik, dimana beberapa petani masih ada yang menanam lebih dari satu bibit per lubang tanam, walaupun tidak banyak petani yang melakukan hal tersebut.

2. Penerapan budidaya padi dengan sistem SRI ini dilanjutkan karena nilai RCR usahatani tersebut diatas satu, maka usahatani tersebut masuk kategori menguntungkan dan layak untuk dilanjutkan.

\section{DAFTAR PUSTAKA}

Badan Pusat Statistik Provinsi Riau. Riau dalam Angka 2015. Pekanbaru

Filardi, Titah dan Elida, Septina.

Faktor - Faktor Sosial

Ekonomi yang

Mempengaruhi Pendapatan

Usahatani Padi Sawah

Petani Kooperator di Desa

Sungai Geringging

Kecamatan Kampar Kiri

Kabupaten Kampar. Jurnal 
RAT Vol.3 No.1. Januari 2014.

Gafar, Abdul. 2012. Analisis

Usahatani Padi Sawah

(Oryza Sativa) Pola Tanam

System of Rice

Intensification (SRI) di

Desa Rambah Baru

Kecamatan Rambah Samo

Kabupaten Rokan Hulu,

Skripsi. Fakultas Pertanian

Universitas Riau. Pekanbaru.

Hernanto, F. 2003. Ilmu Usahatani.

Penebar Swadaya. Jakarta.

Krisnandhi, S. 2009. Menggerakkan dan Membangun Pertanian. Yasaguna, Jakarta.

Mutakin, J. 2007. Budidaya dan Keunggulan Padi Organik Metode SRI (System of Rice

Intensification). Garut Jawa Barat.

Soekartawi, 2002. Analisis

Usahatani. UI - Press.

Jakarta.

Sukirno, S. 2002. Pengantar Teori

Mikro Ekonomi. Raja

Grafindo Persada.

Jakarta. 